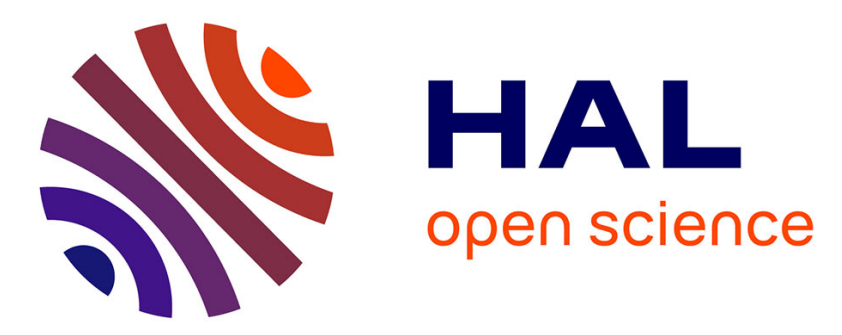

\title{
Phosphine-pyridonate ligands containing octahedral ruthenium complexes: Access to esters and formic acid
}

\author{
A.R. R Sahoo, F. Jiang, Christian Bruneau, G.V.M. V M Sharma, S. Suresh, \\ T. Roisnel, V. Dorcet, M. Achard
}

\section{- To cite this version:}

A.R. R Sahoo, F. Jiang, Christian Bruneau, G.V.M. V M Sharma, S. Suresh, et al.. Phosphinepyridonate ligands containing octahedral ruthenium complexes: Access to esters and formic acid. Catalysis Science \& Technology, 2017, 7 (31), pp.3492-3498. 10.1039/c7cy00932a . hal-01581224

HAL Id: hal-01581224

https://hal-univ-rennes1.archives-ouvertes.fr/hal-01581224

Submitted on 6 Oct 2017

HAL is a multi-disciplinary open access archive for the deposit and dissemination of scientific research documents, whether they are published or not. The documents may come from teaching and research institutions in France or abroad, or from public or private research centers.
L'archive ouverte pluridisciplinaire HAL, est destinée au dépôt et à la diffusion de documents scientifiques de niveau recherche, publiés ou non, émanant des établissements d'enseignement et de recherche français ou étrangers, des laboratoires publics ou privés. 


\title{
Phosphine-Pyridonate Ligands Containing Octahedral Ruthenium Complexes : Access to Esters and Formic Acid
}

\author{
A. R. Sahoo, ${ }^{a}$ F. Jiang, ${ }^{a}$ C. Bruneau, ${ }^{a}$ G. V. M. Sharma, ${ }^{b}$ S. Suresh, ${ }^{b}$ T. Roisnel, $^{a}$ V. Dorcet $^{a}$ and M. Achard ${ }^{a} *$ \\ * Corresponding authors \\ a UMR6226, Institut des Sciences Chimiques de Rennes, Université de Rennes1, Campus de Beaulieu, 35042 Rennes Cedex, France \\ E-mail: mathieu.achard@univ-rennes1.fr \\ b Organic and Biomolecular chemistry Division, CSIR-IICT, Hyderabad-500007, India
}

The preparation of three well-defined ruthenium complexes arising from phosphine-pyridon-e/-ate ligands is described. Solvent dependant Lewis acidic species formation was observed with these complexes. Selective formation of acetal or ester from primary alcohols was observed in the presence of these catalysts. Preliminary evaluation of these complexes in base free hydrogenation of carbon dioxide is also reported.

\section{Introduction}

Catalytic hydrogen transfer processes ranging from hydrogenation and dehydrogenation represent an important research field strengthened by the recent applications related to biomass transformations, carbon dioxide valorization and liquid organic hydrogen carrier's development. ${ }^{[1-3]}$ Noticeable breakthroughs were obtained during the last decade on acceptorless ester formation from alcohols and more recently on base free $\mathrm{CO}_{2}$ hydrogenation, thanks to the use of metal-ligand cooperative catalytic systems based on pincer type or finely tuned ligands. ${ }^{[4-7]}$ While formic acid production still requires the development of catalysts operating at milder reaction conditions and low pressure; in dehydrogenation, the access to tunable catalytic systems allowing the selective formation of selected dehydrogenated products by simple modification of the reaction conditions is of great interest. 2-Pyridone based ranging from bidentate to pincer-containing ligands have attracted interest of the researchers and found promising applications in hydrogen transfer processes such as dehydrogenation of alcohols, ${ }^{[8 a, b, d, g]}$ carbonyl reduction, ${ }^{[8 \mathrm{c}, \mathrm{f}, \mathrm{h}, \mathrm{i}]} \beta$-alkylation of amines, ${ }^{[8 \mathrm{e}]}$ formate production, ${ }^{\left[{ }^{[\mathrm{k}]}\right.}$ ester ${ }^{[8 \mathrm{l}]}$ and carboxylate formation from primary alcohol. ${ }^{[8 \mathrm{k}]}$ In turn, phosphine-pyridon-e/-ate ligand are an interesting class of hybrid ligands. Among them, non-chelating 6(diphenylphosphino)-2-pyridon-e/-ate ligand, known as (PyphosH/Pyphos) has found wide applications for the preparation of metal-metal bonded polynuclear complexes. ${ }^{[9 a]}$ This latter, lately renamed 6-DPPon has also found wide applications in self assembling system for hydroformylation. ${ }^{[\mathrm{b}]}$ Based on the previous findings of Brunner who demonstrated that chelating $O$ alkylated phosphine-pyridones could undergo deprotection, ${ }^{[10]}$ we reported the direct access to the corresponding phosphinepyridone for the catalytic hydrogenation of unfunctionalized ketones and for acetal formation from primary alcohols. ${ }^{[1]}$

Herein we report the preparation of new well-defined ruthenium complexes featuring proton responsive phosphine-pyridone ligands. Preliminary evaluation in tunable acceptorless dehydrogenation of primary alcohols is investigated for the production of acetals or esters as well as their evaluation in the base free hydrogenation of carbon dioxide.

\section{Results and discussion}

Synthesis and characterization of ruthenium(II) complexes

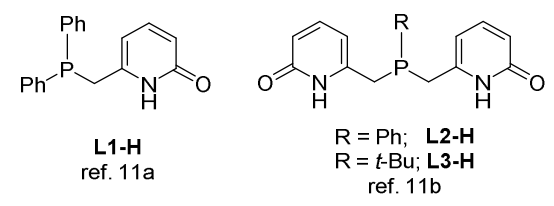

Figure $\mathbf{1}$ Ligands L1-H, L2-H and L3-H used in this study.

With our reported new ligands in hand (Figure 1), we investigated the access to the corresponding well-defined octahedral ruthenium complexes with $\mathrm{RuCl}_{2}\left(\mathrm{PPh}_{3}\right)_{3}$ as common metallic precursor (Scheme 1). Among the five possible isomers, treatment of two equivalents of $\mathbf{~} \mathbf{1}-\mathbf{H}$ with one equivalent of $\mathrm{RuCl}_{2}\left(\mathrm{PPh}_{3}\right)_{3}$ in chloroform solution resulted in the selective formation of the yellow Ru-1 in $60 \%$ isolated yield. Characterization by NMR spectroscopy and successful crystallization demonstrated the selective coordination of the tridentate ligand in a fac mode and selective formation of the $c i s(\mathrm{Cl}, \mathrm{Cl})$ isomer. Hydrogen bonding interaction between the hydroxyl groups and the chloride atoms favoured the selective formation of this isomer, thus contrasting with the corresponding ruthenium analogue featuring a phosphine-picoline ligand. ${ }^{[12]}$ The use of the tridentate ligand $\mathbf{L 2 - H}$ with the same metallic precursor afforded the corresponding yellow Ru-2 complex where the chloride atom in trans relationship with the phosphorus atom of $\mathbf{L 2}-\mathbf{H}$, is interacting with the two hydroxyl groups of the ligand. Interestingly, NMR 
spectroscopy in $\mathrm{CDCl}_{3}$ demonstrated the formation of the neutral complex whereas the use of $\mathrm{CD}_{3} \mathrm{OD}$ highlighted the immediate formation of the resulting red cationic complex. This behaviour was confirmed with the use of the more basic tridentate ligand L3-H which led to the square planar pyramidal cationic 16 è complex Ru-3 where the methanol molecule acts as proton relay. These observations confirm that the formation of Lewis acidic species shielded by the two protonated pyridone moieties and the concomitant assistance of an alcohol can easily occur from these complexes. ${ }^{[13,14 c]}$ For all the synthesized complexes described above, solid state structures support the aromatized structure of the pyridone moieties (Figure 2).

\section{Applications in catalytic dehydrogenation and hydrogenation}

With these well-defined complexes in hand, we next investigated their reactivity in dehydrogenation of primary alcohols (Table 1). Reaction of benzyl alcohol $1 \mathbf{a}$ in the absence of base in THF resulted in the selective formation of the corresponding acetal $2 \mathbf{a}$ albeit in lower yields than with the previously described iridium complexes (entries 2-4). ${ }^{[11,13]}$ Interestingly, in a basic environment created by the addition of sodium hydroxide, the selectivity was completely shifted from acetal to ester in $50 \%$ yield along with benzaldehyde (entry 5). Replacing THF by toluene led to complete conversion into benzyl benzoate $3 a$ in $94 \%$ isolated yield (entry 7). To the best of our knowledge, there is only one precedent report in the literature accounting for the selective formation of acetal or ester by simple modification of the reaction conditions. ${ }^{[13]}$ Under similar conditions, the use of Ru-1 lowered selectivity whereas the use of Ru-3 decreased the conversion (entries 6 and 8). Other hydroxide bases were also evaluated such as $\mathrm{KOH}$ and $\mathrm{LiOH}$. However, the catalytic activities and selectivities were altered suggesting an effect on the metal cation on the reaction efficiency (entries 7, 11, 12). ${ }^{[8]]}$ As expected, complete conversion towards the ester was also observed with the use of a catalytic amount of BnONa generated by the prior addition of sodium (entry 10). Under our optimal catalytic conditions, reaction scope was next examined with benzylic alcohols affording 63 to $94 \%$ isolated yield (Scheme 2). Notably, no side dehalogenation occurred with halogenated benzylic alcohols $\mathbf{1 e}$ and 1f. Aliphatic primary alcohols were selectively converted into the corresponding esters $\mathbf{3 g}$ - $\mathbf{i}$ in up to $85 \%$ isolated yields. The use of citronellol

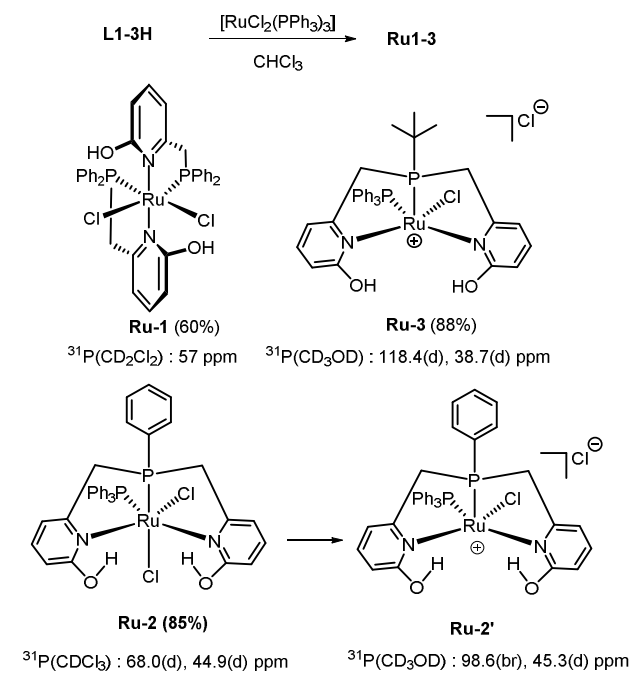

Scheme 1 Preparation of the well-defined Ru1-3 from $\mathrm{RuCl}_{2}\left(\mathrm{PPh}_{3}\right)_{3}$.

gave the bioester $\mathbf{3} \mathbf{j}$ without noticeable isomerized side products whereas undec-10-en-1-ol led to a mixture of isomerized esters (not presented). Under our optimal catalytic conditions, reaction of benzaldehyde $\mathbf{4 a}$ afforded the corresponding benzyl benzoate $3 a$ in $100 \%$ yield according to a

Table 1 Benzyl benzoate from benzyl alcohol $1 a^{a}$

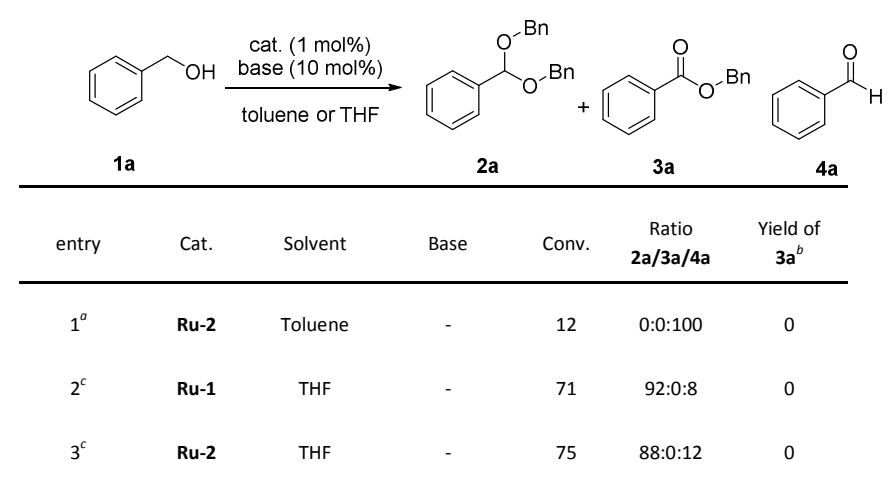




$\begin{array}{lcccccc}4^{c} & \text { Ru-3 } & \text { THF } & - & 56 & 96: 0: 4 & 0 \\ 5 & \text { Ru-2 } & \text { THF } & \text { NaOH (10) } & 67 & 0: 80: 20 & 50 \\ 6^{a} & \text { Ru-1 } & \text { Toluene } & \text { NaOH (10) } & 94 & 0: 50: 50 & 43 \\ 7^{a} & \text { Ru-2 } & \text { Toluene } & \text { NaOH (10) } & 100 & 0: 100: 0 & 99(94) \\ 8^{a} & \text { Ru-3 } & \text { Toluene } & \text { NaOH (10) } & 75 & 0: 98: 2 & 73 \\ 9^{a} & \text { Ru-2 } & \text { Toluene } & \text { tBuOK (10) } & 100 & 0: 77: 21 & 77 \\ 10^{d} & \text { Ru-2 } & \text { Toluene } & \text { BnONa (10) } & 100 & 0: 100: 0 & 99 \\ 11^{a} & \text { Ru-2 } & \text { Toluene } & \text { LiOH (10) } & 41 & 0: 95: 5 & 39 \\ 12^{a} & \text { Ru-2 } & \text { Toluene } & \text { KOH (10) } & 85 & 0: 98: 2 & 84\end{array}$

${ }^{a}$ Experimental conditions: all reactions were performed under an inert atmosphere of argon and carried out with benzyl alcohol 1 a $(0.5 \mathrm{mmol})$, precatalyst $(1 \mathrm{~mol} \%)$ in a closed Schlenk tube in toluene $(0.5 \mathrm{~mL})$ at $150{ }^{\circ} \mathrm{C}$ for $16 \mathrm{~h} .{ }^{b}$ Conversions and $\mathrm{GC}$ yields were determined by GC analysis with dodecane $(30 \mu \mathrm{L})$ as internal standard and the number in parenthesis corresponds to the isolated yield after purification by column chromatography. ${ }^{c}$ Reaction carried out with $0.5 \mathrm{~mL}$ of THF at $170{ }^{\circ} \mathrm{C}$ for $24 \mathrm{~h} .{ }^{d} \mathrm{BnONa}$ was generated by the addition of $\mathrm{Na}$ to benzyl alcohol 1a.
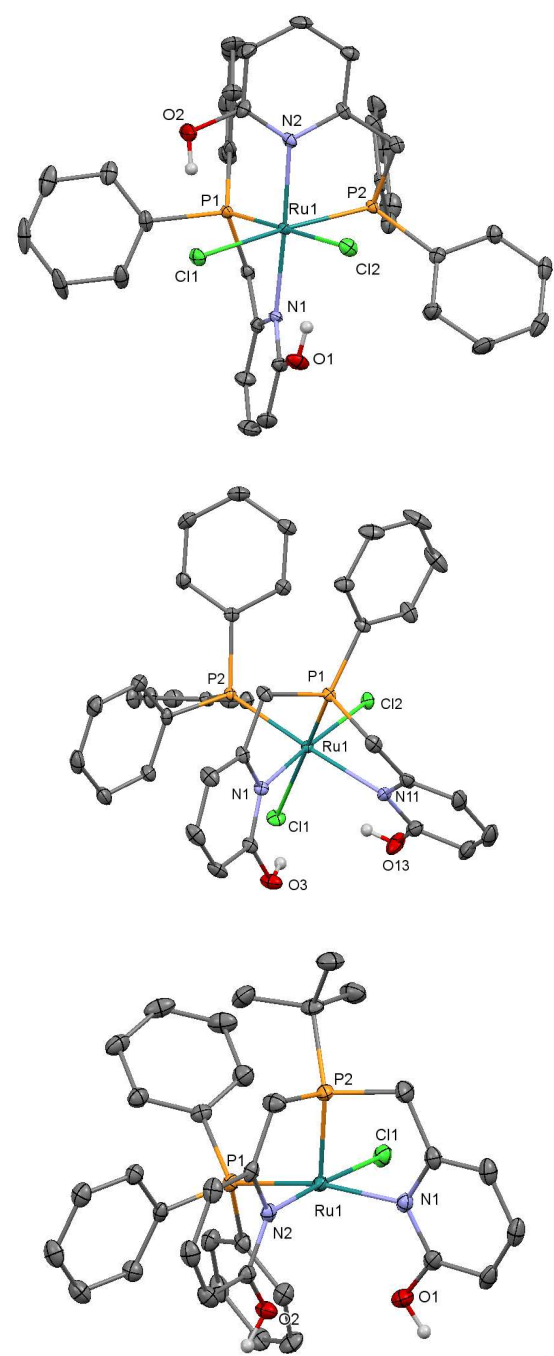

Fig. 2 X-ray structure of Ru1-3. Selected bond lengths, interatomic distances $(\AA)$ and angles $\left({ }^{\circ}\right)$, Ru-1.C $\mathbf{C H}_{2} \mathbf{C l}_{2}$ : Ru1-N1 2.170(3); Ru1-N2 2.146(3); Ru1-P1 2.2423(9); Ru1-P2 2.252(1); Ru1-Cl1 2.499(1); Ru1-Cl2 25329(9); O2-Cl1 2.887; O1-Cl2 2.968; Cl2-Ru1-Cl2 85.15(3); P1-Ru1-P2 95.62(4); N1-Ru1N2 177.0(1). Ru-2.CHCl 3 : Ru1-N1 2.160(2); Ru1-N11 2.232(2); Ru1-P1 2.2024(6); Ru1-P2 2.3230(6); Ru1-Cl1 2.5499(6); Ru1-Cl2 2.4126(6); O3-Cl1 2.941; O13-Cl1 2.960; N1-Ru1-N11 90.35(6); P2-Ru1-Cl2 92.94(2); Cl1-Ru1-P1 171.44(2). Ru-3.MeOH Ru1-N1 2.107(2); Ru1-N2 2.094(2); Ru1-P1 

crystallographic data for Ru-1, Ru-2, Ru-3.

Tishchenko reaction (Scheme 3). ${ }^{[14]}$ Moreover, equimolar reaction of octan-1-ol $1 \mathbf{g}$ with benzaldehyde 4 a led to the formation of the four possible esters with a statistical distribution. ${ }^{[5 \mathrm{~d}, 15]}$ During the treatment of benzyl benzoate 3a with octan-1-ol $1 \mathrm{~g}$ the four expected esters were observed along with the major formation of $\mathbf{3 l}$ with a $50 \%$ yield indicating that transesterification also occurred. ${ }^{[16]}$ Having established that Ru-2 allowed the formation of ester from primary alcohol or aldehyde in the presence of hydroxide base, we focused our attention on its reactivity. Treatment of Ru-2 in a MeOH/ $\mathrm{CH}_{3} \mathrm{CN}$ mixture in the presence of two equivalent of potassium hydroxide afforded the Ru-4 complex (Scheme 4). Among the possible tautomers, solid state structure and

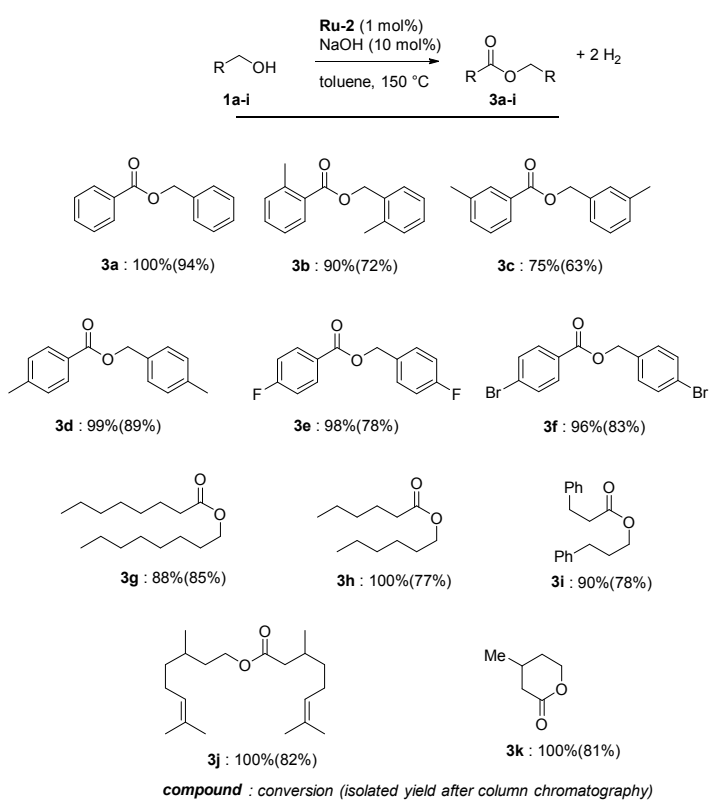

Scheme 2 Preparation of various esters from aliphatic and benzylic alcohols

NMR analyses tend to suggest the formation of the hydroxo complex $($ C136-O138 $=1.30(2) \AA)$ (Figure 3$)$. $^{\text {[h] }}$ Interestingly, evaluation of Ru-4 in dehydrogenation of benzyl alcohol 1a under optimized reaction conditions (Table 1 entry 7 ) led to an active dehydrogenation catalyst with $53 \%$ yield of 3 a suggesting that the simple introduction of the acetonitrile

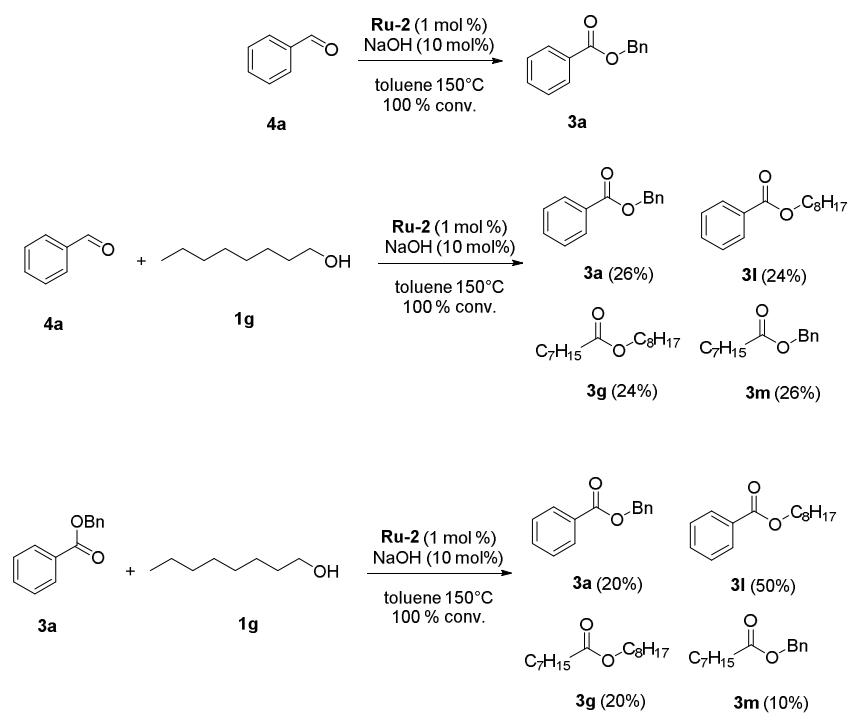

Scheme 3 Competitive experiments

ligand has a profound impact on the conversion. Taken into account the structure of Ru-4 and the effect of the metallic cation, these results tend to support the formation of an active 


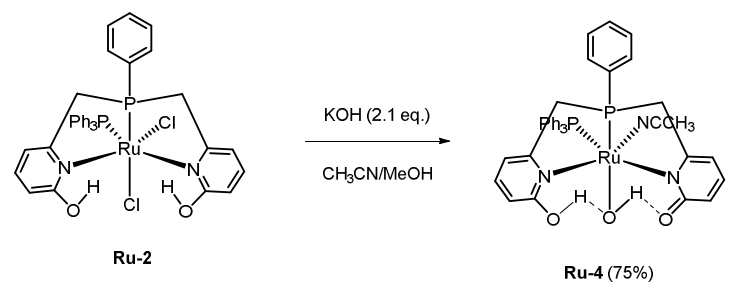

Scheme 4 Reactivity of Ru-2 in the presence of hydroxide base.

anionic ruthenium species. ${ }^{[17]}$ Keeping in mind previous reports on dehydrogenation, acetalization ${ }^{[11,13]}$ and Tishchenko reaction, ${ }^{[14]}$ possible mechanisms are depicted in Figure 4 . On the basis of the results obtained during this study, under neutral conditions, it involves an outer sphere nucleophilic attack on a coordinated hemiacetal in $\mathbf{C}$ arising from the transient formation of the Lewis acidic ruthenium

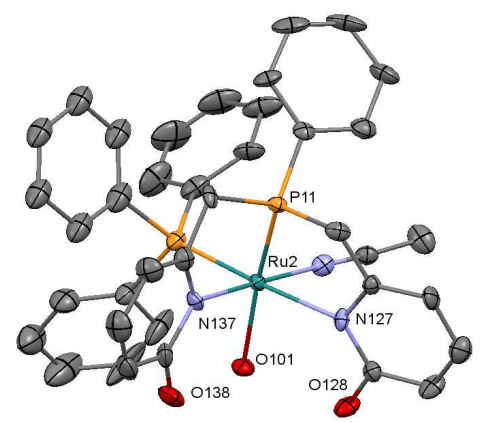

Fig. 3 X-ray structure of Ru4.0.5 $\mathbf{C H}_{2} \mathbf{C l}_{2}$ Selected bond lengths, interatomic distances ( $\AA$ ) and angles ('): Ru2-N127 2.23(1); Ru2-N137 2.17(1); Ru2-P11 2.217(3); Ru2-P12 2.307(3); Ru2-N111 2.01(1); O138-O101 2.538; O128-O101 2.524; C126-O128 1.26(1); C136-O138 1.30(2). CCDC 1468966 contains the supplementary crystallographic data for $\mathbf{R u}-\mathbf{4}$

species $\mathbf{E}$ for acetal formation ${ }^{[13]}$ followed presumably with the formation of a ruthenium monohydride species $\mathbf{B} / \mathbf{B}^{\prime}$. $^{[11]}$ Due to the low concentration of aldehyde during these reactions and basic conditions leading to easy formation of the pyridone rutheniuem species $\mathbf{K}$, in the case of the ester formation, an inner sphere mechanism involving a coordinated aldehyde and an alkoxide is more likely. However, at this stage of this research, the activation of the aldehyde intermediate by the protonated pyridone ring rather than the metallic center via an outer sphere process cannot totally be ruled out. ${ }^{[14 c]}$ Keeping in mind the recent reports on base free hydrogenation of carbon dioxide with well-defined ruthenium and iridium complexes containing PTA (1,3,5-triaza-7-phosphaadamantane), ACRIPHOS (4,5-bis(diphenylphosphino)acridine), azole or pyridone based ligands, we investigated the activity of our complexes in the additive-free hydrogenation of carbon dioxide. ${ }^{[2 b, 7]}$ Taking advantage of the recent contributions of Laurenczy and coworkers highlighting the beneficial influence of solvent such as dmso acting as hydrogen bond acceptor toward formic acid production, we next evaluated the catalytic activities of Ru-1, Ru-2 and Ru-3 under these experimental conditions. Well-defined complexes Ru-2 and Ru-3 featuring tridentate phosphine-pyridone ligands were found to be active in the hydrogenation of carbon dioxide at $50{ }^{\circ} \mathrm{C}$ leading to a formic acid concentration up to 0.07 mol. $\mathrm{L}^{-1}$ (Table 2 , entries 2 and 3). Astonishingly, under similar reaction conditions, hydrogenation in the presence of the complex Ru-1 led to a fourfold more active catalytic system affording around $0.2 \mathrm{M}\left[\mathrm{HCO}_{2} \mathrm{H}\right]$ at only 10 bar of $\mathrm{CO}_{2}$ (entry 1 ). The reaction temperature was found to be crucial and under similar pressure, temperature below or above $50{ }^{\circ} \mathrm{C}$ altered the catalytic activity (entry 1 compared to 5,9 and 10$).{ }^{[7 a]}$ 

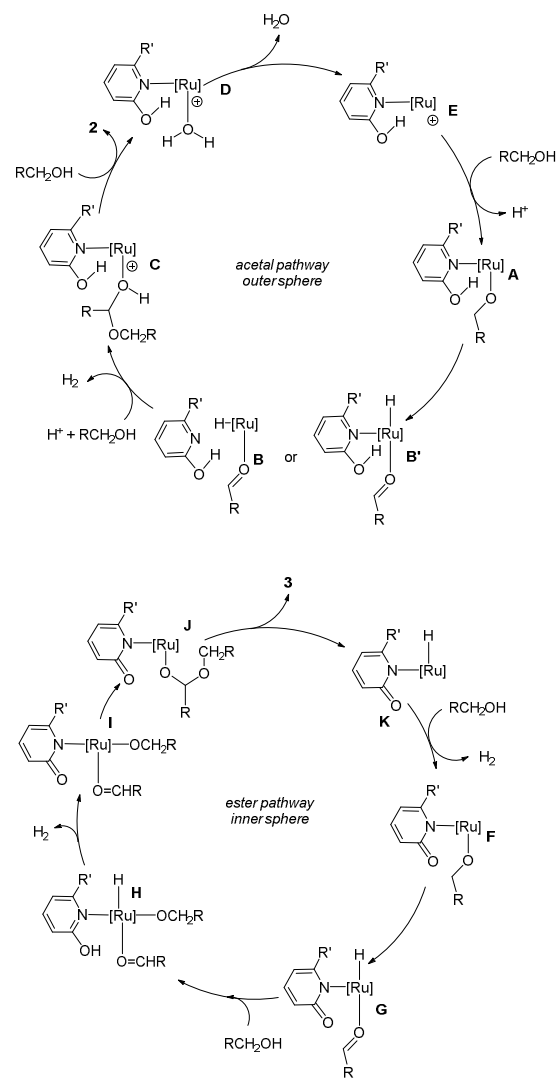

Fig. 4 Proposed pathways accounting on acetal and ester formation.

Increasing the hydrogen pressure had a minimal incidence on the result whereas increasing the pressure of carbon dioxide provided better catalytic activity to reach a 205 TON (entry 7

Table 2 Base free $\mathrm{CO}_{2}$ hydrogenation ${ }^{a}$

\begin{tabular}{|c|c|c|c|c|c|c|}
\hline \multicolumn{7}{|c|}{ Ru1-3 ( $6 \mu \mathrm{mol})$} \\
\hline \multicolumn{3}{|r|}{$\mathrm{CO}_{2}$} & $\begin{array}{r}\text { dmso } \\
50\end{array}$ & $\overrightarrow{\mathrm{H}_{2}}$ & \multicolumn{2}{|l|}{$\mathrm{HCO}_{2} \mathrm{H}$} \\
\hline entry & Cat. & $p \mathrm{CO}_{2} / p \mathrm{H}_{2}$ & $t[\mathrm{~h}]$ & $\mathrm{T}\left({ }^{\circ} \mathrm{C}\right)$ & TON & {$\left[\mathrm{HCO}_{2} \mathrm{H}\right]$} \\
\hline 1 & Ru-1 & $10 / 50$ & 16 & 50 & $115-131$ & $0.19-0.22 \mathrm{M}$ \\
\hline 2 & Ru-2 & $10 / 50$ & 16 & 50 & $33-40$ & $0.05-0.07 \mathrm{M}$ \\
\hline 3 & Ru-3 & $10 / 50$ & 16 & 50 & 31 & $0.06 \mathrm{M}$ \\
\hline 4 & Ru-1 & $10 / 60$ & 72 & 50 & $355-370$ & $0.57-0.60 \mathrm{M}$ \\
\hline 5 & Ru-1 & $10 / 50$ & 16 & 30 & 65 & $0.11 \mathrm{M}$ \\
\hline 6 & Ru-1 & $10 / 70$ & 16 & 50 & 137 & $0.23 \mathrm{M}$ \\
\hline 7 & Ru-1 & $20 / 50$ & 16 & 50 & 205 & $0.34 \mathrm{M}$ \\
\hline 8 & Ru-1 & $30 / 40$ & 16 & 50 & 170 & $0.30 \mathrm{M}$ \\
\hline 9 & Ru-1 & $10 / 50$ & 16 & 70 & 80 & $0.13 \mathrm{M}$ \\
\hline 10 & Ru-1 & $10 / 50$ & 16 & 100 & 55 & $0.08 \mathrm{M}$ \\
\hline
\end{tabular}

${ }^{a}$ Experimental conditions: all reactions were performed in a stainless $20 \mathrm{~mL}$ reactor under the indicated pressure of $\mathrm{CO}_{2}$ and $\mathrm{H}_{2}$. TON were determined by ${ }^{1} \mathrm{H}$ NMR in the presence of internal standard $(100 \mu \mathrm{L})$.

compared to 6 and 1). Finally, up to $0.6 \mathrm{~mol}^{-1}{ }^{-1}$ of formic acid could be achieved after $72 \mathrm{~h}$ reaction time (entry 4$)$ thus competing with the best reported results which usually require high pressure and longer reaction times. ${ }^{[7,18]}$ 


\section{Conclusions}

In conclusion, we have reported the synthesis of three new well-defined ruthenium complexes featuring proton responsive phosphine-pyridone ligands. Solvent dependent formation of the neutral and cationic complexes was demonstrated. Selective formation of acetal or ester was observed by simple modification of the reaction conditions. Competitive experiments highlighted the catalytic activity of such system in dehydrogenation of primary alcohols and Tishchenko reactions. Whereas tridentate ligands afforded better results in dehydrogenation, an opposite trend was observed in the seminal base and additivefree hydrogenation of carbon dioxide leading up to $0.6 \mathrm{M}$ formic acid concentration in dimethyl sulfoxide.

\section{Experimental section}

\section{Synthesis of the complex Ru-1}

A $25 \mathrm{~mL}$ Schlenk tube with magnetic stirrer was charged with the ligand L1-H (100 mg, $0.34 \mathrm{mmol}$ ) in degassed chloroform (5 mL) under argon atmosphere. After 5 minutes of stirring, $\left[\mathrm{RuCl}_{2}\left(\mathrm{PPh}_{3}\right)_{3}\right](163 \mathrm{mg}, 0.17 \mathrm{mmol})$ was added to the solution. The resulting clear red solution was allowed stir at room temperature under an inert atmosphere for 6 hours. The completion of the reaction was confirmed by the disappearance of the peak at $-11 \mathrm{ppm}$ in ${ }^{31} \mathrm{P}$ NMR. Then solvent was evaporated to minimum volume $(\sim 1 \mathrm{~mL})$ under vacuum. Subsequent addition of diethyl ether $(4 \mathrm{~mL})$ furnished bright yellow coloured solid. Washing the above solid with diethyl ether (3*4 $\mathrm{mL}$ ) afforded the desired complex with $60 \%$ yield $(77 \mathrm{mg}, 0.10 \mathrm{mmol})$. Recrystallization of the complex by slow diffusion of diethylether in methanol furnished crystals suitable for $X$-ray diffraction studies. ${ }^{1} \mathrm{H} N M R\left(400 \mathrm{MHz}, \mathrm{CD}_{2} \mathrm{Cl}_{2}\right): \delta 12.33(\mathrm{~s}, 2 \mathrm{H}), 7.69(\mathrm{t}, J=7.8 \mathrm{~Hz}, 2 \mathrm{H}), 7.32-$ $7.29(\mathrm{~m}, 3 \mathrm{H}), 7.19(\mathrm{t}, J=7.2 \mathrm{~Hz}, 4 \mathrm{H}), 7.15-7.11(\mathrm{~m}, 4 \mathrm{H}), 7.03-6.99(\mathrm{~m}, 4 \mathrm{H}), 6.80(\mathrm{q}, J=7.3 \mathrm{~Hz}, 5 \mathrm{H}), 6.49(\mathrm{t}, J=8.5 \mathrm{~Hz}, 4 \mathrm{H}), 4.53-4.46(\mathrm{~m}, 2 \mathrm{H})$, 3.89-3.82 (m, 2H); ${ }^{31} \mathrm{P}\{1 \mathrm{H}\}$ NMR $\left(162 \mathrm{MHz}, \mathrm{CD}_{2} \mathrm{Cl}_{2}\right): \delta 57.52 ;{ }^{13} \mathrm{C}\{1 \mathrm{H}\} \mathrm{NMR}\left(101 \mathrm{MHz}, \mathrm{CD}_{2} \mathrm{Cl}_{2}\right): \delta 170.6$ (quat-C), $161.3($ quat-C), $140.0(\mathrm{CH})$, 135.9 (quat-C), 135.5 (quat-C), 134.6 (quat-C), 134.2 (quat-C), $132.4\left(\mathrm{t}, J_{\mathrm{P}-\mathrm{C}}=4.3 \mathrm{~Hz}, \mathrm{CH}\right), 130.8\left(\mathrm{t}, J_{\mathrm{P}-\mathrm{C}}=4.3 \mathrm{~Hz}, \mathrm{CH}\right), 130.0(\mathrm{CH}), 129.7(\mathrm{CH})$, $128.8\left(\mathrm{t}, J_{\mathrm{P}-\mathrm{C}}=4.7 \mathrm{~Hz}, \mathrm{CH}\right), 128.1\left(\mathrm{t}, J_{\mathrm{P}-\mathrm{C}}=4.8 \mathrm{~Hz}, \mathrm{CH}\right), 114.5\left(\mathrm{t}, J_{\mathrm{P}-\mathrm{C}}=5.3 \mathrm{~Hz}, \mathrm{CH}\right), 111.1(\mathrm{CH}), 44.6\left(\mathrm{~d}, J_{\mathrm{P}-\mathrm{C}}=18.2 \mathrm{~Hz}, \mathrm{CH}_{2}\right), 44.4\left(\mathrm{~d}, J_{\mathrm{P}-\mathrm{C}}=18.2 \mathrm{~Hz}\right.$, $\mathrm{CH}_{2}$ ); HRMS(ESI-TOF): calc'd for $\mathrm{C}_{36} \mathrm{H}_{32} \mathrm{~N}_{2} \mathrm{O}_{2} \mathrm{P}_{2} \mathrm{Cl}{ }_{2} \mathrm{Ru}[\mathrm{M}]^{+}$758.0354; found 758.0358. Anal. Calcd for $\mathrm{C}_{36} \mathrm{H}_{32} \mathrm{~N}_{2} \mathrm{O}_{2} \mathrm{P}_{2} \mathrm{Cl}_{2} \mathrm{Ru} \mathrm{CH}_{2} \mathrm{Cl}_{2}: \mathrm{C}, 52.69 ; \mathrm{H}$, 4.06; N, 3.32. Found: $\mathrm{C}, 52.99 ; \mathrm{H}, 4.07 ; \mathrm{N}, 3.30$.

\section{Synthesis of Ru-2}

A $25 \mathrm{~mL}$ Schlenk tube with magnetic stirrer was charged with the ligand $\mathbf{L} 2-\mathbf{H}$ (100 $\mathrm{mg}, 0.31 \mathrm{mmol}$ ) in degassed chloroform (5 mL) under argon atmosphere. After 5 minutes of stirring, $\left[\mathrm{RuCl}_{2}\left(\mathrm{PPh}_{3}\right)_{3}\right](297 \mathrm{mg}, 0.31 \mathrm{mmol})$ was added to the solution. The colour of the solution changed from dark brown to opaque pale yellow after 10 minutes of vigorous stirring. The resulting solution was allowed stir at room temperature under an inert atmosphere for 2 hours. The completion of the reaction was confirmed by the disappearance of the peak at $14 \mathrm{ppm}$ in ${ }^{31} \mathrm{P}$ NMR. Then solvent was removed by cannulation. Washing the yellow solid with diethyl ether $(3 \times 4 \mathrm{~mL})$ afforded the desired complex with $85 \%$ yield $(200 \mathrm{mg}, 0.26 \mathrm{mmol})$. Recrystallization of the complex by slow diffusion of pentane in chloroform furnished crystals suitable for X-ray diffraction studies. The complex becomes cationic when dissolved in methanol. ${ }^{1} \mathrm{H} \mathrm{NMR}(400 \mathrm{MHz}, \mathrm{CDCl})$ : $\delta 12.24(\mathrm{~s}, 1 \mathrm{H})$, $11.9(\mathrm{~s}, 1 \mathrm{H}), 7.68-7.58(\mathrm{~m}, 6 \mathrm{H}), 7.47-7.05(\mathrm{~m}, 11 \mathrm{H}), 6.95-6.92(\mathrm{~m}, 5 \mathrm{H}), 6.66-6.57(\mathrm{~m}, 3 \mathrm{H}), 6.09(\mathrm{~d}, J=8.1 \mathrm{~Hz}, 1 \mathrm{H}), 4.02\left(\mathrm{dd}, J_{1}=16.8 \mathrm{~Hz}, J_{2}=\right.$ 11.6 Hz, $1 \mathrm{H}), 3.63-3.57(\mathrm{~m}, 2 \mathrm{H}), 3.29\left(\mathrm{dd}, J_{1}=16.8 \mathrm{~Hz}, J_{2}=12.5 \mathrm{~Hz}, 1 \mathrm{H}\right) ;{ }^{31} \mathrm{P}\left\{{ }^{1} \mathrm{H}\right\} \mathrm{NMR}\left(162 \mathrm{MHz}, \mathrm{CDCl}_{3}\right): \delta 68.0(\mathrm{~d}, J=35.9 \mathrm{~Hz}), 44.9(\mathrm{~d}, J=$ $36.0 \mathrm{~Hz}) ;{ }^{1} \mathrm{H}$ NMR $\left(400 \mathrm{MHz}, \mathrm{CD}_{3} \mathrm{OD}\right): \delta 7.74-7.66(\mathrm{~m}, 3 \mathrm{H}), 7.45(\mathrm{t}, J=7.6 \mathrm{~Hz}, 1 \mathrm{H}), 7.38-7.33(\mathrm{~m}, 6 \mathrm{H}), 7.29-7.25(\mathrm{~m}, 5 \mathrm{H}), 7.21-7.12(\mathrm{~m}, 8 \mathrm{H})$, $6.78(\mathrm{~d}, J=7.5 \mathrm{~Hz}, 1 \mathrm{H}), 6.72(\mathrm{~d}, J=8.3 \mathrm{~Hz}, 1 \mathrm{H}), 6.02(\mathrm{~d}, J=8.3 \mathrm{~Hz}, 1 \mathrm{H}), 4.23\left(\mathrm{dd}, J_{1}=17.7 \mathrm{~Hz}, J_{2}=11.4 \mathrm{~Hz}, 1 \mathrm{H}\right), 3.95-3.87(\mathrm{~m}, 2 \mathrm{H}), 3.70\left(\mathrm{dd}, J_{1}\right.$ $\left.=18.9 \mathrm{~Hz}, J_{2}=13.6 \mathrm{~Hz}, 1 \mathrm{H}\right) ;{ }^{31} \mathrm{P}\left\{{ }^{1} \mathrm{H}\right\}$ NMR $\left(162 \mathrm{MHz}, \mathrm{CD}_{3} \mathrm{OD}\right): \delta 98.6(\mathrm{br}), 45.3(\mathrm{~d}, J=33.8 \mathrm{~Hz}) ;{ }^{13} \mathrm{C}\left\{{ }^{1} \mathrm{H}\right\} \mathrm{NMR}\left(101 \mathrm{MHz}, \mathrm{CD}_{3} \mathrm{OD}\right): \delta 167.4$ (quat-C), 166.6 (quat-C), 160.0 (quat-C), 157.3 (quat-C), $141.6(\mathrm{CH}), 139.2(\mathrm{CH}), 134.9$ (d, $\left.\mathrm{J}_{\mathrm{P}-\mathrm{C}}=10.3 \mathrm{~Hz}, \mathrm{CH}\right), 134.5$ (quat-C), 134.1 (quat-C), $132.6(\mathrm{CH}), 132.4(\mathrm{CH}), 130.8\left(\mathrm{~d}, J_{\mathrm{P}-\mathrm{C}}=2.4 \mathrm{~Hz}, \mathrm{CH}\right), 130.3\left(\mathrm{~d}, J_{\mathrm{P}-\mathrm{C}}=11.6 \mathrm{~Hz}, \mathrm{CH}\right), 128.9\left(\mathrm{~d}, J_{\mathrm{P}-\mathrm{C}}=9.6 \mathrm{~Hz}, \mathrm{CH}\right), 116.1\left(\mathrm{~d}, J_{\mathrm{P}-\mathrm{C}}=11.6 \mathrm{~Hz}, \mathrm{CH}\right), 115.8$ $\left(\mathrm{d}, J_{\mathrm{P}-\mathrm{C}}=12.6 \mathrm{~Hz}, \mathrm{CH}\right), 109.6(\mathrm{CH}), 108.2(\mathrm{CH}), 47.1\left(\mathrm{~d}, J_{\mathrm{P}-\mathrm{C}}=31.9 \mathrm{~Hz}, \mathrm{CH}_{2}\right.$ ), 40.6 (d, $J_{\mathrm{P}-\mathrm{C}}=34.0 \mathrm{~Hz}, \mathrm{CH}$ ); HRMS(ESI-TOF): calc'd for $\mathrm{C}_{36} \mathrm{H}_{32} \mathrm{~N}_{2} \mathrm{O}_{2} \mathrm{P}_{2} \mathrm{Cl}_{2} \mathrm{Ru}[\mathrm{M}]^{+}$758.0354; found 758.0356. Anal. Calcd for $\mathrm{C}_{36} \mathrm{H}_{32} \mathrm{~N}_{2} \mathrm{O}_{2} \mathrm{P}_{2} \mathrm{Cl}_{2} \mathrm{Ru} \mathrm{H}_{2} \mathrm{O}: \mathrm{C}, 55.68 ; \mathrm{H}, 4.41 ; \mathrm{N}, 3.61$. Found: $\mathrm{C}, 55.47 ; \mathrm{H}$, $4.37 ; \mathrm{N}, 3.54$.

\section{Synthesis of Ru-3}

A $25 \mathrm{~mL}$ Schlenk tube with magnetic stirrer was charged with the ligand $\mathbf{L} 3-\mathbf{H}$ ( $50 \mathrm{mg}, 0.16 \mathrm{mmol}$ ) in degassed chloroform (3 mL) under argon atmosphere. After 5 minutes of stirring, $\left[\mathrm{RuCl}_{2}\left(\mathrm{PPh}_{3}\right)_{3}\right](158 \mathrm{mg}, 0.16 \mathrm{mmol})$ was added to the solution. The resulting clear red solution was allowed stir at room temperature under an inert atmosphere for 2 hours. The completion of the reaction was confirmed by the disappearance of the peak at $6 \mathrm{ppm}$ in ${ }^{31} \mathrm{P}$ NMR. Then solvent was evaporated to minimum volume $(\sim 1 \mathrm{~mL})$ under vacuum. Subsequent addition of diethyl ether $(4 \mathrm{~mL})$ furnished brick red coloured solids. Washing the above solid with diethyl ether $(3 \times 4 \mathrm{~mL})$ afforded the desired complex with $88 \%$ yield $(103 \mathrm{mg}, 0.14 \mathrm{mmol})$. Recrystallization of the complex by slow diffusion of diethyl ether in methanol furnished crystals suitable for X-ray diffraction studies. ${ }^{1} \mathrm{H}$ NMR $\left(400 \mathrm{MHz}, \mathrm{CD}_{3} \mathrm{OD}\right): \delta 7.90(\mathrm{br}, 3 \mathrm{H}), 7.67(\mathrm{t}, J=7.9 \mathrm{~Hz}, 1 \mathrm{H}), 7.31(\mathrm{br}, 9 \mathrm{H})$, $7.18(\mathrm{~d}, J=7.4 \mathrm{~Hz}, 2 \mathrm{H}), 7.09(\mathrm{t}, J=7.9 \mathrm{~Hz}, 2 \mathrm{H}), 6.74(\mathrm{~d}, J=7.4 \mathrm{~Hz}, 1 \mathrm{H}), 6.66(\mathrm{~d}, J=8.2 \mathrm{~Hz}, 1 \mathrm{H}), 5.82(\mathrm{~d}, J=8.2 \mathrm{~Hz}, 1 \mathrm{H}), 4.09\left(\mathrm{dd}, J_{1}=17.6 \mathrm{~Hz}\right.$, $\left.J_{2}=9.1 \mathrm{~Hz}, 1 \mathrm{H}\right), 3.76-3.61(\mathrm{~m}, 2 \mathrm{H}), 3.43-3.31(\mathrm{~m}, 1 \mathrm{H}), 1.09(\mathrm{~d}, J=16.2 \mathrm{~Hz}, 9 \mathrm{H}) ;{ }^{31} \mathrm{P}\left\{{ }^{1} \mathrm{H}\right\} \mathrm{NMR}\left(162 \mathrm{MHz}, \mathrm{CD}_{3} \mathrm{OD}\right): \delta 118.4(\mathrm{~d}, J=30.6 \mathrm{~Hz}), 38.7$ $(\mathrm{d}, J=30.4 \mathrm{~Hz}) ;{ }^{13} \mathrm{C}\left\{{ }^{1} \mathrm{H}\right\}$ NMR $\left(101 \mathrm{MHz}, \mathrm{CD}_{3} \mathrm{OD}\right): \delta 167.0$ (quat-C), $166.4\left(\mathrm{~d}, J_{\mathrm{P}-\mathrm{C}}=1.2 \mathrm{~Hz}\right.$, quat-C), 160.7 (quat-C), $158.0\left(\mathrm{~d}, J_{\mathrm{P}-\mathrm{C}}=1.2 \mathrm{~Hz}\right.$, quat-C), $141.5(\mathrm{CH}), 139.0(\mathrm{CH}), 135.8(\mathrm{br}$, quat $-\mathrm{C}), 131.0(\mathrm{br}, \mathrm{CH}), 129.0\left(\mathrm{~d}, J_{\mathrm{P}-\mathrm{C}}=9.4 \mathrm{~Hz}, \mathrm{CH}\right), 116.0\left(\mathrm{~d}, J_{\mathrm{P}-\mathrm{C}}=11.4 \mathrm{~Hz}, \mathrm{CH}\right), 115.5\left(\mathrm{~d}, J_{\mathrm{P}-\mathrm{C}}=\right.$ $11.2 \mathrm{~Hz}, \mathrm{CH}), 109.2(\mathrm{CH}), 107.9(\mathrm{CH}), 41.8\left(\mathrm{~d}, J_{\mathrm{P}-\mathrm{C}}=28.8 \mathrm{~Hz}, \mathrm{CH}_{2}\right), 39.8\left(\mathrm{~d}, J_{\mathrm{P}-\mathrm{C}}=26.2 \mathrm{~Hz}, \mathrm{CH}_{2}\right), 33.2\left(\mathrm{~d}, \mathrm{~J}_{\mathrm{P}-\mathrm{C}}=32.7 \mathrm{~Hz}\right.$, quat-C), $26.4\left(\mathrm{~d}, \mathrm{~J}_{\mathrm{P}-\mathrm{C}}=2.7\right.$ $\mathrm{Hz}, \mathrm{CH}_{3}$ ); HRMS(ESI-TOF): calc'd for $\mathrm{C}_{34} \mathrm{H}_{35} \mathrm{~N}_{2} \mathrm{O}_{2} \mathrm{P}_{2} \mathrm{CINaRu}{ }^{+}[\mathrm{M}-\mathrm{H}+\mathrm{Na}]^{+}$725.0798; found 725.0801. Anal. Calcd for $\mathrm{C}_{34} \mathrm{H}_{36} \mathrm{~N}_{2} \mathrm{O}_{2} \mathrm{P}_{2} \mathrm{Cl}{ }_{2} \mathrm{Ru}$ : $\mathrm{C}, 55.29$; $H, 4.91 ; N, 3.79$. Found: $C, 54.50 ; H, 4.99 ; N, 3.80$. 


\section{Synthesis of Ru-4}

A $25 \mathrm{~mL}$ Schlenk tube with magnetic stirrer was charged with the complex Ru-1 (50 mg, $0.066 \mathrm{mmol}$ ) in a mixture of methanol (1 mL) and acetonitrile $(4 \mathrm{~mL})$ under argon atmosphere. After 5 minutes of stirring, $\mathrm{KOH}(8 \mathrm{mg}, 0.14 \mathrm{mmol})$ was added to the solution. The resulting clear yellow solution was allowed stir at room temperature under an inert atmosphere for 6 hours. Then solvent was removed under vacuum. Solubilizing the complex with dichloromethane and cannula filtration after removed the insoluble $\mathrm{KCl}$. Removal of solvent from the filtrate afforded the desired faint yellow complex with $75 \%$ yield $(37 \mathrm{mg}, 0.05 \mathrm{mmol})$. Recrystallization of the complex by slow diffusion of pentane in dichloromethane furnished crystals suitable for X-ray diffraction studies. ${ }^{1} \mathrm{H} N M R\left(400 \mathrm{MHz}, \mathrm{CD}_{2} \mathrm{Cl}_{2}\right): \delta 12.22(\mathrm{br}, 2 \mathrm{H}), 7.53-$ $7.50(\mathrm{~m}, 1 \mathrm{H}), 7.42-7.38(\mathrm{~m}, 2 \mathrm{H}), 7.30-7.23(\mathrm{~m}, 5 \mathrm{H}), 7.17-7.05(\mathrm{~m}, 13 \mathrm{H}), 6.99-6.95(\mathrm{~m}, 1 \mathrm{H}), 6.13-6.06(\mathrm{~m}, 3 \mathrm{H}), 5.83(\mathrm{~d}, J=8.5 \mathrm{~Hz}, 1 \mathrm{H}), 3.46-$ $3.23(\mathrm{~m}, 3 \mathrm{H}), 2.75\left(\mathrm{dd}, J_{1}=15.8 \mathrm{~Hz}, J_{2}=8.8 \mathrm{~Hz}, 1 \mathrm{H}\right), 2.02(\mathrm{~s}, 3 \mathrm{H}) ;{ }^{31} \mathrm{P}\left\{{ }^{1} \mathrm{H}\right\} \mathrm{NMR}\left(162 \mathrm{MHz}, \mathrm{CD}_{2} \mathrm{Cl}_{2}\right): \delta 67.08(\mathrm{~d}, J=28.5 \mathrm{~Hz}), 48.95(\mathrm{~d}, J=29.2$ $\mathrm{Hz}$ ); HRMS(ESI-TOF): calc'd for $\mathrm{C}_{38} \mathrm{H}_{34} \mathrm{~N}_{3} \mathrm{O}_{2} \mathrm{P}_{2} \mathrm{Ru}\left[\mathrm{M}+\mathrm{H}+\mathrm{H}_{2} \mathrm{O}\right]^{+} 728.1164$; found 728.1172.

\section{General procedure for the dehydrogenation}

A clean and dry Schlenk tube $(5 \mathrm{~mL})$ was charged with complex Ru-2 $(0.005 \mathrm{mmol}, 1 \mathrm{~mol} \%)$ in degassed toluene $(0.5 \mathrm{~mL}) . \mathrm{NaOH}(0.05 \mathrm{mmol}$, $10 \mathrm{~mol} \%)$ was added to this opaque yellow solution. After stirring for 5 minutes, the appropriate alcohol $(0.5 \mathrm{mmol})$ was mixed. This reaction mixture was stirred in a preheated oil bath at $150{ }^{\circ} \mathrm{C}$. The reaction was monitored by TLC and GC. After the completion of the reaction, the reaction mixture was cooled to room temperature and solvent was evaporated. The crude reaction mixture was purified by silica gel column chromatography using petroleum ether and ethyl acetate mixture as eluent to get the desired ester.

\section{General procedure for the formic acid generation}

Degassed dimethyl sulfoxide $(4 \mathrm{~mL})$ and Ru-1 $(5 \mathrm{mg}, 6.59 \mu \mathrm{mol})$ were added in a $20 \mathrm{~mL}$ autoclave. The reactor was sealed, applied vacuum, then filled with argon (ten cycles) and then ended with vacuum. Carbon dioxide was introduced at 10 bar and the mixture was stirred at this pressure for 5 minutes. Then, molecular hydrogen was introduced under stirring at an initial pressure of 20 bar and slowly increased to reach a total pressure of $60 \mathrm{bar}\left(\mathrm{pH}_{2} \sim 50 \mathrm{bar}\right)$. The resulting mixture was then stirred at $50{ }^{\circ} \mathrm{C}$ for $16 \mathrm{~h}$. After, the autoclave was cooled down to room temperature. Then the unreacted hydrogen and $\mathrm{CO}_{2}$ were carefully released. Addition of $100 \mu \mathrm{L}$ of dimethylformamide followed by stirring for three minutes and analysis by ${ }^{1} \mathrm{H}$ NMR (within 30 mins) allowed the determination of the turnover number and formic acid concentration.

\section{Aknowledgments}

CEFIPRA/IFCPAR N ${ }^{\circ} 5105-4$ is acknowledged for a fellowship to A.R.S. and the funding of this project.

\section{Notes and references}

1 (a) M. Trincado, D. Banerjee and H. Grützmacher, Energy Environ. Sci., 2014, 7, 2464; (b) R. H. Crabtree, Chem. Rev., 2017, DOI : 10.1021/acs.chemrev.6b00556.

2 (a) J. Eppinger and K. -W. Huang, ACS Energy Lett., 2017, 2, 188; (b) J. Klankermayer, S. Wesselbaum, K. Beydoun and W. Leitner, Angew. Chem. Int. Ed. 2016, 55, 7296.

3 M. Aresta, A. Dibenedetto and E. Quaranta, J. Catal., 2016, 343, 2.

4 J. R. Khusnutdinova and D. Milstein, Angew. Chem. Int. Ed., 2015, 54, 12236.

5 (a) Y. Blum, D. Reshef and Y. Shvo, Tetrahedron Lett., 1981, 22, 1541; (b) S. -I. Murahashi, K. -i. Ito, T. Naota and Y. Maeda, Tetrahedron Lett., 1981, 22, 5327; (c) Blum, Y.; Shvo, Y. J. Organomet. Chem. 1985, 282, C7; (d) S. Murahashi, T. Naota, K. i. Ito, Y. Maeda and H. Taki, J. Org. Chem., 1987, 52, 4319.

6 (a) J. Zhang, G. Leitus, Y. Ben-David and D. Milstein, J. Am. Chem. Soc., 2005, 127, 10840; (b) A. Solvhoj and R. Madsen, Organometallics, 2011, 30, 6044; (c) D. Spasyuk and D. Gusev, Organometallics, 2012, 31, 5239; (d) M. Nielsen, H. Junge, A. Kammer and M. Beller, Angew. Chem. Int. Ed., 2012, 51, 5711.

7 Selected recent reports on base free hydrogenation of $\mathrm{CO}_{2}:(a)$ S. Moret, P. J. Dyson and G. Laurenczy, Nat. Commun., 2014, 5, 4017 ; (b) K. Sordakis, A. Tsurusaki, M. Iguchi, H. Kawanami, Y. Himeda and G. Laurenczy, Chem. Eur. J., 2016, 22, 15605; (c) S.-M. Lu, Z. Wang, J. Li, J. Xiao and C. Li, Green Chem., 2016, 18, 4553; (d) K. Rohmann, J. Kothe, M. W. Haenel, U. Englert, M. Hölscher and W. Leitner, Angew. Chem. Int. Ed., 2016, 55, 8966.

8 Selected references on 2-pyridone ligands : (a) K.-i. Fujita, N. Tanino and R. Yamaguchi, Org. Lett., 2007, 9, 109; (b) A. M. Royer, T. B. Rauchfuss and D. L. Gray, Organometallics, 2010, 29, 6763; (c) I. Nieto, M. S. Livings, J. B. Sacci III, L. E. Reuthers, M. Zeller and E. T. Papish, Organometallics, 2011, 30, 6339; (d) R. Kawahara, K.-i. Fujita and R. Yamaguchi, Angew. Chem. Int. Ed., 2012, 51, 12790; (e) S. Zeyneb, B. Sundararaju, M. Achard and C. Bruneau, Green Chem, 2013, 15, 775; (f) C. M. Moore and N. K. Szymczak, Chem. Commun., 2013, 49, 400; (g) S. Chakraborty, P. E. Piszel, W. B. Brennessel and W. D. Jones, Organometallics, 2015, 34, 5203; $(h)$ C. M. Moore, B. Bark and N. K. Szymczack, ACS Catal., 2016, 6, 1981; (i) J. Shi, B. Hu, D. Gong, S. Shang, G. Hou and D. Chen, Dalton Trans., 2016, 45, 4828; (j) E. W. Dahl, T. Louis-Goff and N. Szymczack, Chem. Commun., 2017, 53, 2287; (k) L. Wang, N. Onishi, K. Murata, T. Hirose, J. T. Muckerman, E. Fujita and Y. Himeda, ChemSusChem, 2017, 10, 1071; (I) S. Y. de Boer, T. J. Korstanje, S. R. La Rooij, R. Kox, J. N. H. Reek and J. I. van der Vlugt, Organometallics, 2017, 36, 1541.

9 (a) K. Mashima, H. Nakano and A. Nakamura, J. Am. Chem. Soc., 1993, 115, 11632; (b) B. Breit and W. Seiche, J. Am. Chem. Soc., 2003, 125, 6608.

10 H. Brunner, A. Köllnberger, A. Mehmood, T. Tsuno and M. Zabel, J. Organomet. Chem., 2004, 689, 4244.

11 (a) F. Jiang, M. Achard, V. Dorcet, T. Roisnel and C. Bruneau, Eur. J. Inorg. Chem., 2015, 4312; (b) A. R. Sahoo, F. Jiang, C. Bruneau, G. V. M. Sharma, S. Suresh and M. Achard, RSC Adv., 2016, 6, 100554.

12 T. Miura, I. E. Held, S. Oishi, M. Naruto and S. Saito, Tetrahedron Lett., 2013, 54, 2674.

13 (a) C. Gunanathan, L. J. W. Shimon and D. Milstein, J. Am. Chem. Soc., 2009, 131, 3146; (b) E. Kossoy, Y. Diskin-Posner, G. Leitus and D. Milstein, Adv. Synth. Catal., 2012, 354, 497.

14 (a) T. Ito, H. Horino, Y. Koshiro and A. Yamamoto, Bull. Chem. Soc. Jpn., 1982, 55, 504.;(b) M.-O. Simon and S. Darses, Adv. Synth. Catal. ,2010, 352, 305; (c) S. A. Morris and D. Gusev, Angew. Chem. Int. Ed., 2017, 56, 6228. 
15 J. Cheng, M. Zhu, C. Wang, J. Li, X. Jiang, Y. Wei, W. Tang, D. Xue and J. Xiao, Chem. Sci., 2016, 7, 4428.

16 A. Dubey and E. Khaskin, ACS Catal., 2016, 6, 3998.

17 For an anionic iridium species involving pyridone ligand see: K.-i. Fujita, R. Kawahara, T. Aikawa and R. Yamaguchi, Angew. Chem. Int. Ed., 2015, 54, 9057.

18 For comparison with previously reported complexes under base and additive free conditions, ref. $7 \mathrm{a}:\left[\mathrm{HCO}_{2} \mathrm{H}\right]=1.93 \mathrm{M} p$ tot $=100$ bar, $120 \mathrm{~h}$; ref. $7 \mathrm{~b}:\left[\mathrm{HCO}_{2} \mathrm{H}\right]=0.1 \mathrm{M} \mathrm{p}$ tot= 50 bar, $50 \mathrm{~h}$, ref. $7 \mathrm{c}\left[\mathrm{HCO}_{2} \mathrm{H}\right]=0.12 \mathrm{M} \mathrm{p}$ tot= 50 bar, $30 \mathrm{mins} ; \mathrm{ref} .7 \mathrm{~d}:[\mathrm{HCO} \mathrm{H}]=0.33 \mathrm{M}$ ptot $=120$ bar, $16 \mathrm{~h}$ 